УДК 581.1+581.5(477)

Г. С. Россихіна-Галича, Л. В. Богуславська, В. В. Лашко

Дніпропетровський національний університет ім. Олеся Гончара

\title{
ВПЛИВ ГЕРБІЦИДНИХ ПРЕПАРАТІВ \\ НА ФЕРМЕНТАТИВНУ АКТИВНІСТЬ І ПОЛІПЕПТИДНИЙ СКЛАД СТИГЛОГО ЗЕРНА ПШЕНИЦ
}

\begin{abstract}
Оцінено чутливість озимої пшениці сорту «Землячка» до дії гербіцидних препаратів Гранстар, Естерон, Гроділ Максі, Пума Супер. Гербіцидна обробка посівів пригнічус активність ферментів-антиоксидантів в 1,7-4,8 раза (супероксиддисмутаза), 1,2-1,4 раза (пероксидаза) у стиглому зерні пшениці, зміни каталазної активності дослідних варіантів були незначними. За дії гербіцидів виявлено якісні зміни поліпептидного складу насіння. Для поліпептидів із Mr 14,8, 15,2 (крім Гроділ Макci), 20,0 кДа визначено стабільне збільшення вмісту порівняно 3 контролем. Виявлено комплексні зміни - результат відновлення та підтримання гомеостазу рослинного організму.
\end{abstract}

А. С. Россихина-Галычая, Л. В. Богуславская, В. В. Лашко

Днепропетровский национальный университет им. Олеся Гончара

\section{ВЛИЯНИЕ ГЕРБИЦИДНЫХ ПРЕПАРАТОВ НА ФЕРМЕНТАТИВНУЮ АКТИВНОСТЬ И ПОЛИПЕПТИДНЫЙ СОСТАВ ЗРЕЛОГО ЗЕРНА ПШЕНИЦЫ}

Исследована чувствительность озимой пшеницы сорта «Землячка» к действию гербицидных препаратов Гранстар, Эстерон, Гродил Макси, Пума Супер. Гербицидная обработка посевов подавляет активность ферментов-антиоксидантов в 1,7-4,8 раза (супероксиддисмутаза), 1,2-1,4 раза (пероксидаза) в спелом зерне пшеницы, изменения каталазной активности опытных вариантов незначительные. При действии гербицидов обнаружены качественные изменения полипептидного состава зерна. Для полипептидов с Mr 14,8, 15,2 (кроме Гродил Макси), 20,0 кДа определено стабильное увеличение содержания по сравнению с контролем. Выявленные комплексные изменения являются результатом восстановления и поддержки гомеостаза растительного организма.

\author{
A. S. Rossikhina-Galycha, L. V. Boguslavskaja, V. V. Lashko \\ Oles Honchar Dnipropetrovsk National University
}

\section{EFFECT OF HERBICIDES ON ENZYMATIC ACTIVITY AND POLYPEPTIDE COMPOSITION OF MATURE WHEAT CORN}

The sensitivity of winter wheat variety "Zemljachka” to the action of herbicides Granstar, Esteron, Grodil Maxi and Puma Super was investigated. It is established that the herbicide treatment of crops suppressed the activity of antioxidant enzymes in mature wheat grain: superoxide dismutase - by 1.7-4.8 times, and peroxidase - 1.2-1.4 times. The changes in catalase activity were reliable, but insignificant. Under the action of herbicides the qualitative changes in polypeptide composition of the grains were found. For polypeptides with the Mr 14.8, 15.2 (except Grodil Maxi) and 20.0 kDa was determined a steady increase in content in comparison with the control. Revealed complex changes are the result of the restoration and maintenance of the plant homeostasis. 


\section{Вступ}

У сучасному рослинництві спостерігається інтенсивне зростання обсягів застосування комплексних препаратів захисту рослин. Галузь захисту рослин у світі - одна 3 найпотужніших [16]. Гербіциди дозволяють отримати значну кількість додаткової продукції, підвищити економічну ефективність обробки культур. Головна увага при цьому приділяється стану рудеральної рослинності, іiі загибелі, а реакція культурних рослин на дію гербіцидів враховується недостатньо [6]. Проблема впливу гербіцидів на онтогенез культурних рослин потребує глибшого аналізу. Виробники гербіцидних препаратів акцентують увагу на відсутності токсичного ефекту при їх застосуванні на сільськогосподарські культури [15]. Рядом дослідників установлено, що за дії цих фізіологічно-активних речовин відбуваються зміни лабільних показників окисновідновного метаболізму клітин (антиоксидантних ферментів) [3; 13; 14], зниження мітотичної активності меристем коренів і хромосомні аберації [4], зниження життєздатності пилку [10], схожості та енергії проростання насіння $[3 ; 7 ; 15]$, пригнічення ростових процесів і, як наслідок, - зменшення насіннєвої продукції рослин [7; 15].

Зниження врожайності культурних рослин корелює 3 накопиченням залишкових кількостей гербіцидів і появою нових речовин у зерні [7]. Ксенобіотики, змінюючи фотосинтез, впливають на спряжені метаболічні процеси, й у першу чергу на білковий обмін і поліпептидний склад розчинних білків $[1 ; 5 ; 7 ; 14]$. У відповідь на абіотичні, біотичні та антропогенні чинники синтезується специфічний набір стресових білків $[1 ; 3 ; 14 ; 15]$, серед яких найважливіші - ферменти-детоксикатори активних форм кисню - супероксиддисмутаза, каталаза та пероксидаза [2; 7].

Мета роботи - оцінити чутливість пшениці сорту «Землячка» за змінами активності оксидоредуктаз і поліпептидного складу зерна до гербіцидної обробки посівів.

\section{Матеріал і методи досліджень}

Об’єкт дослідження - стигле зерно пшениці сорту «Землячка», отримане у польових експериментах, проведених у 2011 році згідно з [8] на дослідних ділянках Інституту сільського господарства степової зони НААН України (м. Дніпропетровськ) після попередника вико-вівсяної суміші. Грунтовий покрив - звичайні середньосуглинкові чорноземи з умістом гумусу 4-5 \%. Гербіциди вносили у таких дозах: Гранстар (25 г/га), Гроділ Максі (100 мл/га) та бакові суміші Гранстар (15 г/га) з Естероном (0,6 л/га), Естерон $(0,8$ л/га) з Пумою Екстра $(0,8$ л/га). За контрольне вважали зерно пшениці, зібране на ділянках без гербіцидної обробки з ручним виполюванням бур'янів.

У стиглому зерні визначали активність супероксиддисмутази за рівнем гальмування процесу відновлення нітросинього тетразолію за присутності НАДН і феназинметасульфату за Переслегіною [11]. Каталазну активність оцінювали титриметричним методом за Плешковим [12] і виражали в мМоль перекису водню, розкладеного за хвилину. Активність пероксидази визначали за швидкістю реакції окиснення бензидину за Єрмаковим [9] та виражали в умовних одиницях.

Розчинні білки зерна пшениці екстрагували 0,0125 М натрій-боратним буфером ( $p H 10)$ із додаванням $1 \%$ додецилсульфату натрію та $2 \% \beta$-меркаптоетанолу та розділяли методом денатуруючого електрофорезу у градієнтному (10-20 \%) поліакриламідному гелі за [19], використовуючи як маркери РНК-азу (15 кДа), $\alpha$-хімотрипсин (22,5 кДа) та альбумін яєчний (43 кДа). За показником молекулярної ваги поліпептиди умовно поділено на низько- (12-30 кДа) та середньомолекулярні - (30-50 кД). Вміст розчинного білка у зерні визначали загальноприйнятим методом [17]. Денситометрування здійснювали за допомогою програми «Електрофор-менеджер 2.0», розробленої 72 
відділом якості продукції та радіологотоксикологічних досліджень ДПТЦ «Облдержродючість». Отримані дані порівнювали за допомогою $t$-критерію Стьюдента (відмінності вважали достовірними при $p<0,05)$.

\section{Результати та їх обговорення}

Аналіз отриманих даних свідчить про те, що у зерні пшениці з оброблених гербіцидами посівів порівняно з контрольними, активність супероксиддисмутази достовірно знижена (в 1,7 раза) у варіанті застосування бакової суміші Гранстару з Естроном (табл. 1). Знижену активність СОД (в 1,9 раза) зареєстрували за індивідуального впливу препарату Гранстар. Використання Гроділ Максі значно знижувало ферментативний рівень відносно контролю (в 2,6 раза).

Таблиия 1

Вплив гербіцидів на активність супероксиддисмутази, каталази та пероксидази у зерні пшениці

\begin{tabular}{|l|c|c|c|}
\hline \multicolumn{1}{|c|}{ Варіант обробки } & $\begin{array}{c}\text { Супероксиддисмутаза } \\
(M \pm m), \text { ум. од./Г тканини }\end{array}$ & $\begin{array}{c}\text { Каталаза }(M \pm m), \\
\text { мМоль } H_{2} O_{2} / \text { г тканини за } \\
\text { хв. }\end{array}$ & $\begin{array}{c}\text { Пероксидаза }(M \pm m), \\
\text { ум. од./г тканини }\end{array}$ \\
\hline Контроль & $0,81 \pm 0,009$ & $2,52 \pm 0,040$ & $579,8 \pm 3,03$ \\
\hline Гранстар + Естерон & $0,49 \pm 0,003 *$ & $2,28 \pm 0,020 *$ & $663,9 \pm 5,79 *$ \\
\hline Гроділ Максі & $0,31 \pm 0,007 *$ & $2,27 \pm 0,060 *$ & $486,3 \pm 3,92 *$ \\
\hline Естрон + Пума Супер & $0,07 \pm 0,006 *$ & $2,27 \pm 0,030 *$ & $409,0 \pm 0,58 *$ \\
\hline Гранстар & $0,42 \pm 0,012 *$ & $2,46 \pm 0,040 *$ & $463,3 \pm 0,88 *$ \\
\hline
\end{tabular}

Примітка: *- різниця достовірна при $p<0,05$.

Найнижчою активністю характеризувався варіант досліду з баковою сумішшю гербіцидів Естерон і Пума Екстра (в 4,8 раза нижче контрольного варіанта). Зафіксоване зниження активності супероксиддисмутази можливо пов'язане з виснаженням пулу ферменту або його інактивацією за участі активних форм кисню (гідроксильного радикала та пероксиду водню) [2; 18]. На фоні цього відбувалося пригнічення активності пероксидази (на 16-29 \%) та несуттєві зміни каталазної активності (див. табл. 1).

Порівняння вмісту загального білка стиглого зерна пшениці у контролі та за дії гербіцидів виявило такі відмінності (табл. 2). Обробка посівів гербіцидами Гроділ Максі спричинювала незначне зменшення вмісту білка (на 2,5 \%) порівняно $з$ контролем. За дії інших гербіцидних препаратів виявлено підвищення цього показника. Найбільший вміст білка (138,4 \%) відзначений за дії Гранстару.

Табличя 2

Вміст розчинних білків у зерні пшениці за дії гербіцидних препаратів

\begin{tabular}{|l|c|c|c|c|c|}
\hline \multirow{2}{*}{ Характеристика } & \multicolumn{5}{|c|}{ Варіант обробки } \\
\cline { 2 - 6 } & Контроль & Гранстар & Гранстар + Естерон & Гроділ Максі & Естерон + Пума Супер \\
\hline Вміст білка, мг/Г & $6,72 \pm 0,06$ & $9,29 \pm 0,07$ & $8,69 \pm 0,09$ & $6,55 \pm 0,05$ & $7,33 \pm 0,06$ \\
\hline$\%$ до контролю & 100,0 & 138,4 & 129,4 & 97,5 & 109,1 \\
\hline
\end{tabular}

Одночасно з підвищенням вмісту білка спостерігалися зміни якісного його складу. Активні зміни поліпептидного складу білків відмічено для всіх досліджених варіантів (виявлено 21 компонент з Mr 14,8-51,3 кДа як у контролі, так і в дослідних зразках) (табл. 3). За дії гербіциду Гранстар встановлено підвищення вмісту компонентів із $\mathrm{Mr}$ 23,0 та 49,0 кДа на 37 та 63 \% відповідно порівняно з контролем. У варіанті з Гранстар + Естерон виявлено збільшення вмісту компонентів з $\mathrm{Mr}$ 23,0, 28,9, 42,7, 46,8 кДа. Гроділ Максі викликав підвищення вмісту поліпептидів $\mathrm{Mr}$ в області середньомолекулярних значень (42,7, 49,0, 51,3 кДа). За комбінації Естерон + Пума Супер відбувалось підви- 
щення вмісту компонентів Mr 28,9, 35,5, 46,8 кДа. У поліпептидах Mr 14,8, 15,2 (крім Гроділ Максі), 20,0 кДа визначено стабільне збільшення вмісту порівняно $з$ контролем.

Таблиия 3

Вміст (\%) сумарних білків у стиглому зерні пшениці за дії гербіцидів різного походження

\begin{tabular}{|c|c|c|c|c|c|}
\hline \multirow{2}{*}{$\begin{array}{c}\text { мг, } \\
\text { ка }\end{array}$} & \multicolumn{5}{|c|}{ Варіант обробки } \\
\cline { 2 - 6 } & контроль & Гранстар & Гранстар+Естерон & Гроділ Максі & Естерон+Пума Супер \\
\hline 51,3 & 2,91 & 2,16 & 2,15 & 5,17 & 2,47 \\
\hline 49,0 & 17,54 & 28,59 & 13,98 & 19,41 & 15,76 \\
\hline 46,8 & 3,56 & 2,34 & 3,74 & 3,37 & 3,67 \\
\hline 42,7 & 7,97 & 6,40 & 9,19 & 8,23 & 2,13 \\
\hline 40,8 & 0,99 & 0,34 & 0,52 & 0,84 & 0,55 \\
\hline 38,9 & 1,98 & 0,32 & 2,54 & 2,09 & 2,21 \\
\hline 37,2 & 0,87 & 0,74 & 0,46 & 0,48 & 0,50 \\
\hline 35,5 & 4,23 & 2,58 & 4,20 & 4,16 & 4,58 \\
\hline 30,9 & 3,45 & 2,41 & 3,21 & 2,67 & 2,92 \\
\hline 29,5 & 1,74 & 2,04 & 1,57 & 1,27 & 1,75 \\
\hline 28,9 & 8,76 & 6,63 & 9,55 & 7,55 & 11,37 \\
\hline 27,0 & 1,21 & 2,53 & 3,08 & 2,48 & 2,51 \\
\hline 23,0 & 3,09 & 4,23 & 4,11 & 2,31 & 1,00 \\
\hline 21,4 & 1,50 & 1,71 & 1,64 & 2,68 & 1,51 \\
\hline 20,0 & 1,83 & 2,69 & 2,73 & 2,38 & 2,09 \\
\hline 17,8 & 17,54 & 10,36 & 16,16 & 16,30 & 18,13 \\
\hline 17,0 & 12,30 & 8,23 & 8,09 & 9,03 & 10,73 \\
\hline 16,6 & 0,15 & 0,21 & 0,15 & 0,17 & 0,20 \\
\hline 15,9 & 0,85 & 2,15 & 0,81 & 1,71 & 1,54 \\
\hline 15,2 & 6,78 & 8,76 & 7,70 & 5,08 & 10,12 \\
\hline 14,8 & 0,75 & 4,58 & 4,43 & 2,63 & 4,26 \\
\hline
\end{tabular}

За дії всіх досліджених варіантів визначено стабільне зниження вмісту в компонентах Mr 17,0, 17,8, 30,9 кДа, а за впливу Естрон + Пума Супер - підвищення $\mathrm{Mr}$ 35,5 кДа на фоні зниження його вмісту за інших дослідних варіантів. Таким чином, за дії всіх досліджених гербіцидних препаратів визначено зменшення чи підвищення вмісту наявних білкових компонентів.

\section{Висновки}

Виявлено комплексні зміни - результат відновлення та підтримання гомеостазу рослинного організму. Підвищення вмісту білка в зерні має свій прояв у вигляді якісних перебудов поліпептидного складу, але відсутність кількісних змін в електрофоретичному спектрі білків насіння за дії досліджуваних гербіцидних препаратів свідчить про інтенсифікацію синтезу існуючих компонентів. Низький рівень активності ферментів - маркерів розвитку окисного стресу вказує на реалізацію стійкості рослин за участі інших захисних систем організму.

\section{Бібліографічні посилання}

1. Адаптогенез растений к пестицидам / Н. А. Рябченко, Н. П. Коцюбинская, Е. В. Домашнєва и др. - Д. : Пороги, 2000. - 193 с.

2. Бараненко В. В. Супероксиддисмутаза в клетках растений // Цитология. - 2006. - Т. 48, № 6. - С. 465-474.

3. Більчук В. С. Фізіолого-морфологічні особливості репродуктивних органів пшениці за дії гербіцидів різних класів / В. С. Більчук, Г. С. Россихіна, Ю. І. Ткаліч // Наук. вісн. МДУ ім. В. О. Сухомлинського. - 2009. - Вип. 24, № 4 (1). - С. 21-24. 
4. Богуславська Л. В. Особливості цитогенетичних показників апікальної кореневої меристеми кукурудзи за дії хімічних агентів / Л. В. Богуславська, Л. В. Шупранова, О. В. Садоха // Наук. вісн. МДУ ім. В. О. Сухомлинського. - 2009. - Вип. 24, № 4 (1). - С. 32-35.

5. Богуславська Л. В. Реакція білкової системи зони розтягу коренів кукурудзи на дію ксенобіотиків / Л. В. Богуславська, О. М. Вінниченко, С. В. Варданян // Наук. вісн. МДУ ім. В. О. Сухомлинського. - 2009. - Вип. 24, № 4 (1). - С. 35-38.

6. Деева В. П. О последействии гербицидов - производных галоидфеноксикислот - на культурные растения / В. П. Деева, Н. В. Санько // Физиология и биохимия культурных растений. 1990. - Т. 22, № 6. - С. 523-531.

7. Коцюбинская Н. П. Эколого-физиологические аспекты адаптации культурных растений к антропогенным условиям среды. - Д. : Изд-во ДГУ, 1995. - 173 с.

8. Методические рекомендации по проведению полевых опытов с кукурузой / Д. С. Филёв, В. С. Циков, В. И. Золотов и др. - Д. : ВНИИ кукурузы, 1980. - 54 с.

9. Методы биохимического исследования растений / Под ред. А. И. Ермакова. - 3-е изд. - Л. : Агропромиздат, 1987. $-430 \mathrm{c}$.

10. Огінова І. О. Адаптивні реакції репродуктивної сфери сорго до дії гербіцидів // Вісн. Дніпропетр. ун-ту. Біологія. Екологія. - 2006. - № 3/1. - С.135-140.

11. Переслегина И. А. Активность антиоксидантных ферментов слюны здоровых детей // Лабораторное дело. - 1989. - № 11. - С. 20-23.

12. Плешков Б. П. Практикум по биохимии растений. - М. : Колос, 1968. - 183 с.

13. Россихіна Г. С. Особливості впливу гербіцидної обробки на процеси перекисного окислення // Наук. вісн. Ужгород. ун-ту. Біологія. - 2006. - Вип. 18. - С. 76-79.

14. Россихіна Г. С. Активність ферментів переамінування в стиглому зерні рослин гібридної кукурудзи за дії гербіцидних препаратів / Г. С. Россихіна, В. В. Лашко // Вісн. Львів. ун-ту. Серія біол. - 2011. - Вип. 56. - С. 234-238.

15. Хромих Н. О. Вплив гербіцидів нового покоління на фізіолого-біохімічні показники насіння кукурудзи / Н. О. Хромих, Г. С. Россихіна, В. В. Лашко // Вісн. Харків. нац. аграрн. ун-ту. Біологія. - 2011. - Вип. 3. - С. 50-55.

16. Швартау В. В. Регуляція активності гербіцидів за допомогою хімічних сполук. - К. : Логос, 2003. $-267 \mathrm{c}$.

17. Bradford M. M. A rapid and sensitive method for the quantative of microgram quantaties of protein utilizing the principle of protein-dye binding // Anal. Biochem. - 1976. - Vol. 72. - P. 248-254.

18. Inactivation and degradation of $\mathrm{CuZn-SOD}$ by active oxygen species in wheat chloroplasts exposed to photooxidative stress / L. M. Casano, L. D. Gomes, H. R. Lascano et al. // Plant Cell Physiol. 1997. - Vol. 38. - P. 433-440.

19. Laemmli U. K. Cleavage of structural of bacteriophage T-4 // Nature. - 1970. - Vol. 227. - P. 680-685.

Надійшла до редколегії 04.05.2012 